\title{
直交異方性積層材の剛性特性と最適化（円筒殻への応用）
}

\author{
福 永久 雄*
}

(1984年 9 月 20 日受付)

\section{Stiffness Characteristics and Optimization of Orthotropic Laminates (Application to Cylindrical Shells)}

\author{
H. FUKUNAGA*
}

(Received September 20, 1984)

\begin{abstract}
This paper first treats the relation between in-plane and out-of-plane lamination parameters and the relation between lamination parameters and laminate configurations. Next, on the basis of these relations, the laminate configuration which gives the highest buckling stress of orthotropic laminated cylindrical shells under axial compression or external pressure is examined. It is shown that a special cross-ply laminate is the optimal laminate configuration for the buckling of cylindrical shells under external pressure.
\end{abstract}

\section{1. 序}

CFRPのように異方性の強い一方向瀻維強化材料より 成る積層材においては, 各層の繊維の配向角, 積層順序 により面内拉よび面外の剛性が著しく変化する. その結 果, 座屈・振動のような力学的特性も積層構成（各層の 繊維の配向角, 積層順序) により非常に変化するので複 合材料を有効に利用するためには最適な積層構成を選ぶ ことが重要となってくる.

このような剛性支配の力学的特性は, 積層パラメータ の導入により理解しやすくなる. 三木 ${ }^{1)}$ は面内積層パラ メータを用いて面内剛性の評価方法を示した．また，著 者 ${ }^{2-4)}$ は面外積層パラメータを用いて直交異方性積層板 の座屈・振動特性を調べ最適設計を行なった．直交異方 性積層板では，座屈・振動特性を支配するのが面外積層 パラメータだけで面内積層パラメータには依存しないた め座屈荷重や基本固有振動数を最大とする最適積層構成 が比較的容易に得られた.

* 東京大学工学部境界領域研究施設助手 (153 東京 都目黒区駒場 4-6-1)

Research Associate, Inst. of Interdisciplinary Res., Fac. of Eng., University of Tokyo, 46-1, Komaba, Meguro-ku, Tokyo 153, Japan 現在：航空宇宙技術研究所機体一蔀研究員 (182 調布市深大寺東町 7-44-1)

Present address: Researcher, 1st Airframe Div., National Aerospace Laboratory, 7-44-1, Jindaiji-higashi-machi, Chofu 182, Japan
一方, 積層円筒豰においては一般に面内変形と面外変 形とが連成するため, カップリング効果を無視した場合 でも，座屈・振動のような力学的特性は面内積層パラメ 一タと面外積層パラメータの両方に依存する. 面内積層 パラメータと面外積層パラメータとは完全に独立な変数 ではないので，まずこの両者の関係を知る必要がある. 三未融 は $0, \pm \theta_{1}, \pm \theta_{2}$ の 3 種類の配向角から成る積層 材について, ある面内剛性（面内積層パラメータ）のと き必要な面外剛性を与える積層構成を求める手法を示 しているが，積層パラメータを設計変数として用いる最 適設計の観点からは，より一般的な面内積層パラメータ と面外積層パラメータの関係を求める必要がある.

本論文では，まず初めに，ある面内積層パラメータに 対応する面外積㬝パラメータの許容領域を示し, 許容領 域内の面内・面外積層パラメータに対応する積層構成の 求め方を示す. 次に, 積層パラメータ間の関係を用いて カップリング効果を無視した直交異方性積層円筒殼につ いて圧縮・外圧座屈荷重を最大とする積層構成を調べ る.

\section{2. 積層理論と積層パラメータ}

\section{1 剛性と皘層パラメータの関係}

本節では, 後述の議論の準備として, 剛性と積層パラ メータに関する基礎的な事項を述べる

Kirchhoff の仮定に基づく積層理論では，カップリン グ効果を無視すると次の構成関係式が得られる6). 


$$
\left\{\begin{array}{l}
\boldsymbol{N} \\
\boldsymbol{M}
\end{array}\right\}=\left[\begin{array}{cc}
\boldsymbol{A} & 0 \\
0 & \boldsymbol{D}
\end{array}\right]\left[\begin{array}{ll}
\boldsymbol{\varepsilon}_{0} \\
\boldsymbol{\kappa}
\end{array}\right\}
$$

ここで, $\boldsymbol{N}, \boldsymbol{M}$ は合力, 合モーメント, $\boldsymbol{\varepsilon}_{0}, \boldsymbol{x}$ は中央 面昰, 曲率変化であり, $\boldsymbol{A}, \boldsymbol{D}$ は面内および面外剛性を 示す.

面内剛性 $\boldsymbol{A}$ は剛性に関する不変量と面内積廉パラメ ータにより次のように表示できる.

$$
\left\{\begin{array}{l}
A_{11} \\
A_{12} \\
A_{22} \\
A_{66}
\end{array}\right\}=h\left(\begin{array}{ccccc}
1 & \xi_{1} & \xi_{2} & 0 & 0 \\
0 & 0 & -\xi_{2} & 1 & 0 \\
1 & -\xi_{1} & \xi_{2} & 0 & 0 \\
0 & 0 & -\xi_{2} & 0 & 1
\end{array}\right\}\left\{\begin{array}{l}
U_{1} \\
U_{2} \\
U_{3} \\
U_{4} \\
U_{5}
\end{array}\right\}
$$

ここで, $h$ は積層材の板厚であり,$U_{i}(i=1,2, \cdots, 5)$

は Tsai-Pagano ${ }^{7)}$ と類似の剛性に関する不変量である.

$$
\begin{aligned}
& U_{1}=\left[Q_{11}+2\left(Q_{12}+2 Q_{66}\right)+Q_{22}\right] / 4 \\
& U_{2}=\left[Q_{11}-Q_{22}\right] / 2 \\
& U_{3}=\left[Q_{11}-2\left(Q_{12}+2 Q_{66}\right)+Q_{22}\right] / 4 \\
& U_{4}=\left[Q_{11}+Q_{22}+2 Q_{12}-4 Q_{66}\right] / 4 \\
& U_{5}=\left[Q_{11}+Q_{22}-2 Q_{12}\right] / 4
\end{aligned}
$$

また， $\xi_{1} ， \xi_{2}$ は面内積層パラメータで，積層材が中央面 に対称であるとして次のように与えられる.

$$
\begin{aligned}
& \xi_{1} \equiv \frac{1}{h} \int_{-h / 2}^{h / 2} \cos 2 \theta(z) d z=\int_{0}^{1} \cos 2 \theta(u) d u \\
& \xi_{2} \equiv \frac{1}{h} \int_{-h / 2}^{h / 2} \cos ^{2} 2 \theta(z) d z=\int_{0}^{1} \cos ^{2} 2 \theta(u) d u
\end{aligned}
$$

ここで, $\theta(u)$ は繊維の配向角で板厚方向の座標の関数 である.

面外剛性 $\boldsymbol{D}$ に関しても同様に(2)式で

$$
\begin{aligned}
& A_{i j} \rightarrow D_{i j}, h \rightarrow h^{3} / 12 \\
& \xi_{1} \rightarrow \xi_{3}, \xi_{2} \rightarrow \xi_{4}
\end{aligned}
$$

として得られる． $\xi_{3} ， \xi_{4}$ は面外積層パラメータで次のよ らに表わされる.

$$
\begin{aligned}
& \xi_{3}=\frac{12}{h^{3}} \int_{-h / 2}^{h / 2} \cos 2 \theta(z) \cdot z^{2} d z=3 \int_{0}^{1} u^{2} \cos 2 \theta(u) d u \\
& \xi_{4}=\frac{12}{h^{3}} \int_{-h / 2}^{h / 2} \cos ^{2} 2 \theta(z) \cdot z^{2} d z=3 \int_{0}^{1} u^{2} \cos ^{2} 2 \theta(u) d u
\end{aligned}
$$

(4),（6)式で示される積層パラメータには次の関係 が成り立つ.

$$
\begin{aligned}
& -1 \leqq \xi_{1} \leqq 1, \xi_{1}{ }^{2} \leqq \xi_{2} \leqq 1 \\
& -1 \leqq \xi_{3} \leqq 1, \xi_{3}{ }^{2} \leqq \xi_{4} \leqq 1
\end{aligned}
$$

(7)式で示されるように， $\xi_{1}$ と $\xi_{2}$ は $\xi_{1}-\xi_{2}$ 座標上で $\xi_{2}=\xi_{1}{ }^{2}$ の放物線と $\xi_{2}=1$ の直線に囲まれた領域にあ る. $\xi_{3}$ と $\xi_{4}$ についても同様である. また， $\left(\xi_{1}, \xi_{2}\right)$ と 積層構成の関係や $\left(\xi_{3}, \xi_{4}\right)$ と積層構成の関係はすでに知 られており ${ }^{1,2)}$ ，たとえば， $\xi_{2}=\xi_{1}{ }^{2}$ は $\theta=(1 / 2) \cos ^{-1} \xi_{1}$
のアングルブライ積層をボし，このとき $\xi_{3}=\xi_{1}, \xi_{4}=\xi_{2}$ となる. また， $\xi_{2}=1$ は $0^{\circ}, 90^{\circ}$ 層から成る一般的なク ロスプライ積層を示し，このとき $\xi_{4}=1$ となる. 面内剛 性. $A_{i j}$ は $\xi_{1}, \xi_{2}$ の線形関数であり, 面外剛性 $D_{i j}$ は $\xi_{3}, \xi_{4}$ の線形関数であるので，それらの特性は積層パラ メータにより理解が容易となる.

\section{2 積層パラメータの特性と積層構成との関係}

緘維の配向角 $\theta(z)$ を板厚方向に積分して得られた面 内積層パラメータと面外積層パラメータとは独立な変数 ではなくある制約関係がある，本節では，ある面内積層 パラメータ $\left(\xi_{1}, \xi_{2}\right)$ に対する面外積層パラメータ $\left(\xi_{3}\right.$, $\left.\xi_{4}\right)$ の許容領域を調へ，許容領域内の $\left(\xi_{1}, \xi_{2}, \xi_{3}, \xi_{4}\right)$ に対応する積層構成を求めることにする. このために, まず面内積層パラメータに対心する積層構成を 2 種類の 配向角から成る積層材で表示し，それに対応する面外積 層パラメータの許容領域を求める. 次に, このよ5にし て得られた面外積層パラメータの許容領域が配向角の種 類を增加させても払大しないことを示す。

Fig. 1 に亦すようにある面内積層パラメータ $\left(\xi_{1}, \xi_{2}\right)$ を有する点Pが与えられたときの面外積層パラメータ $\left(\xi_{3}, \xi_{4}\right)$ の許容領域を求める. A $(-1,1), \mathrm{B}(1,1)$ と $\mathrm{P}$ を結ぶ值線と放物線との交点をそれぞれ $\mathrm{C}\left(\boldsymbol{\xi} c, \boldsymbol{\xi}_{c}{ }^{2}\right)$, $\mathrm{D}\left(\xi_{D}, \xi_{D}{ }^{2}\right)$ とすると,

$$
\xi_{C}=\left(\xi_{1}+\xi_{2}\right) /\left(1+\xi_{1}\right), \xi_{D}=\left(\xi_{1}-\xi_{2}\right) /\left(1-\xi_{1}\right)
$$

で与えられる. いま, 点 $\mathrm{P}$ の面内積層パラメータに対応 する積層構成を, 点 $\mathrm{P}$ を通る直線と境界 $\left(\xi_{4}=\xi_{3}{ }^{2}, \xi_{4}=\right.$ 1）との交点である 2 点 $\mathrm{E}, \mathrm{F}$ の配向角を用いて表わし, 点 $\mathrm{E}$ が点 $\mathrm{A}$ から点 $\mathrm{C}$ まで放物線上を $180^{\circ}$ 動くとさの面 外積層パラメータの許容領域を求める. $\angle \mathrm{APE}=\alpha$ とし

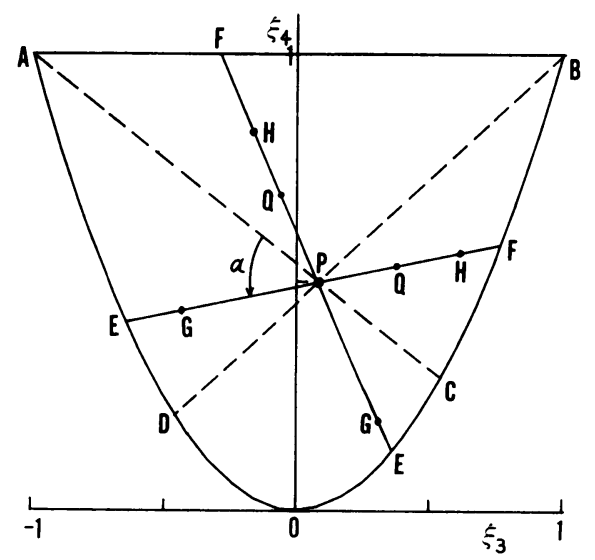

Fig. 1 Relation between in-plane and out-ofplane lamination parameters. 
て, $0 \leqq \alpha \leqq \alpha_{D}$ (ただし $\left.\alpha_{D}=\angle \mathrm{APD}\right)$ と $\alpha_{D} \leqq \alpha \leqq \pi の 2$ 通りの場合を考える.な拈，点 $\mathrm{P} か ゙$ 放物線上にあるとき は $\theta=(1 / 2) \cos ^{-1} \xi_{1}$ のアングルプライ積層を示し，その とさの面外積層パラメータ $\left(\boldsymbol{\xi}_{3}, \boldsymbol{\xi}_{4}\right)$ は $\left(\boldsymbol{\xi}_{1}, \boldsymbol{\xi}_{2}\right)$ と等し くなるので, $\xi_{2}>\xi_{1}{ }^{2}$ の場合を考える.

(1) $0 \leqq \alpha \leqq \alpha_{D}$ のとき

点 $\mathrm{E}$ の座標 $\left(\xi_{E}, \xi_{E}{ }^{2}\right)$ に対して点 $\mathrm{F}$ の坐標 $\left(\xi F, \xi_{F}^{2}\right)$ の $\xi_{F}$ は次のようになる.

$$
\xi_{F}=\left(\xi_{2}-\xi_{1} \xi_{E}\right) /\left(\xi_{1}-\xi_{E}\right)
$$

2 点 $\mathrm{E}, \mathrm{F}$ に対伈する 2 種類の配向角によって点 $\mathrm{P} の$ 面内積層パラメー $\left(\boldsymbol{\xi}_{1}, \boldsymbol{\xi}_{2}\right)$ に対応する積層構成を表示 する. そのとき, $\mathrm{E}, \mathrm{F}$ の配向角 $\theta E, \theta F$ 扰よび板厚 $h_{E}, h_{F}$ は次の值をとる.

$$
\begin{aligned}
& \theta_{E}=(1 / 2) \cos ^{-1} \xi_{E}, \theta_{F}=(1 / 2) \cos ^{-1} \xi_{F} \\
& h_{E}=\left(\xi_{F}-\xi_{1}\right) /\left(\xi_{F}-\xi_{E}\right), h_{F}=1-h_{E}
\end{aligned}
$$

ここで，幾何学的関係から $h_{E}, h_{F}$ はそれぞれ $\mathrm{PF} / \mathrm{EF}$ 扣よび PE/EF に対応している.

上記のように面内積層パラメータ $\left(\xi_{1}, \xi_{2}\right)$ に対応する 積層構成を 2 種類の配向角で表示すると，各配向角を有 する層の板厚は (10) 式に示すように一義的に決定され る.このとき面外積層パラメータ $\left(\xi_{3}, \xi_{4}\right)$ は 2 種類の配 向角から成る積層材の積層順序が指定されれば定まるこ とになる. 点 $\mathrm{P}$ 2 2 点 $\mathrm{E}, \mathrm{F}$ の配向角で表示したとき, 対応する面外積層パラメータ $\left(\boldsymbol{\xi}_{3}, \boldsymbol{\xi}_{4}\right)$ を点 Qとすると, 点Qは值線 EF にあることは明らかでありその座標は次 のようになる.

$$
\begin{gathered}
\left(\xi_{3}, \xi_{4}\right)=\left(\xi_{E}, \xi_{E}{ }^{2}\right)+\lambda\left(\xi_{F}-\xi_{E}, \xi_{F^{2}}-\xi_{E}{ }^{2}\right) \\
h_{F}{ }^{3} \leqq \lambda \leqq 1-h_{E}{ }^{3}
\end{gathered}
$$

ここで, $\lambda=h_{F}{ }^{3}$ となる点 $\mathrm{G} は \theta_{E}$ 層が外層, $\theta_{F}$ 層が

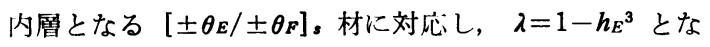
る点 $\mathrm{H}$ は $\theta_{F}$ 層が外層, $\theta_{E}$ 層が内層となる $\left[ \pm \theta_{F} / \pm \theta_{E}\right]_{s}$ 材に対応する. $\theta_{E}$ 層と $\theta_{F}$ 層とを交互に適当に積層する ことにより，点Qは $\mathrm{GH}$ 上を $\mathrm{G} か ら \mathrm{H}$ をで動くことにな る.

次は逆に, 面内積層パラメ一タ $\left(\xi_{1}, \xi_{2}\right)$ に対応する点 $\mathrm{P}$, および許容領域内にある面外積層パラメ一タ $\left(\xi_{3}\right.$, $\xi_{4}$ ）に対応する点Qが与えられたときに，積層構成を佰 線 $\mathrm{PQ}$ と放物線との交点 $\mathrm{E}, \mathrm{F}$ の配向角 $\theta E, \theta F$ を用い て表わすことにする. 点 $\mathrm{E}\left(\xi_{E}, \xi_{E}{ }^{2}\right)$, 点 $\mathrm{F}\left(\xi_{F}, \xi_{F}{ }^{2}\right)$ の座標は直線 $\mathrm{PQ}$ と放物線との交点を示す次の方程式

$$
\xi^{2}-\frac{\xi_{4}-\xi_{2}}{\xi_{3}-\xi_{1}} \xi+\frac{\xi_{1} \xi_{4}-\xi_{2} \xi_{3}}{\xi_{3}-\xi_{1}}=0
$$

の 2 根 $\xi_{E} ， \xi_{F}$ (ただし $\xi_{E} \leqq \xi_{F}$ とする）より得られる. 点 $\mathrm{E}, \mathrm{F}$ に対忍する配向角および点 $\mathrm{P}$ の面内積層パラメ
一タを満足する板厚は(10)式で与えられる．また(12)式 は点 $\mathrm{P} ， \mathrm{Q}$ が一致する場合には使えないが，そのとき は，点 $\mathrm{E}$ 放物線上 $\widehat{\mathrm{AD}}$ の任意の点とし直線 $\mathrm{EP}$ と放物 線 $\overparen{\mathrm{CB}}$ との交点を $\mathrm{F}$ として (9)式より $\xi_{F}$ が求まる.

点Qの面外積層パラメータを満足する積層構成は 2 種 類の配向角であっても積層順序は無数にあるので無数に 存任するが, Fig. 2 に示す $\left[ \pm \theta E / \pm \theta_{F} / \pm \theta E\right]$ s材によっ ても表示できることを以下に示す. 各層の板厚を $h_{E_{1}}$, $h_{F}, h_{E_{2}}$ (たたし $\left.h_{E_{1}}+h_{B_{2}}=h_{E}\right)$ とする.

$$
\left(\xi_{3}, \xi_{4}\right)=\left(\xi_{E}, \xi_{E}^{2}\right)+\lambda_{0}\left(\xi_{F}-\xi_{E}, \xi_{F}^{2}-\xi_{E}^{2}\right)
$$

と表示すると, Fig.2 の積層順序に対しては

$$
\lambda_{0}=h_{F}\left[h_{F}{ }^{2}+3 h_{F} h_{E_{2}}+3 h_{E_{2}}{ }^{2}\right]
$$

となり，また幾何学的関係 $\left(\lambda_{0}=\mathrm{EQ} / \mathrm{EF}\right)$ より

$$
\lambda_{0}=\left(\xi_{3}-\xi_{E}\right) /\left(\xi_{F}-\xi_{E}\right)
$$

となる. (14)式の $\lambda_{0}$ は $h_{E_{2}}$ が $0 \rightarrow h_{E}$ まで変化する間に $h_{F}{ }^{3} \rightarrow 1-h_{E}{ }^{3}$ と動き, Fig.2 の積層構成により線分 $\mathrm{GH}$ 上の任意の点Qを表示でさることがわかる．また，(14）

(15)式より $h_{E_{2}}$ は次式で与えられる.

$$
h_{E_{2}}=\sqrt{12\left(\xi_{3}-\xi_{E}\right) /\left(\xi_{1}-\xi_{E}\right)-3 h_{F}^{2}} / 6-h_{F} / 2
$$

ここで, $h_{F}$ は (10)式で与えられ， $h_{E_{1}}=h_{E}-h_{E_{2}}$ であ る.

(2) $\alpha_{D} \leqq \alpha \leqq \pi$ のとき

点 $\mathrm{E}\left(\xi_{E}, \xi_{E}{ }^{2}\right)$ に対して点 $\mathrm{F}\left(\xi_{F}, 1\right)$ の $\xi_{F}$ は次の ようになる.

$$
\xi_{F}=\xi_{1}+\left(1-\xi_{2}\right)\left(\xi_{1}-\xi_{E}\right) /\left(\xi_{2}-\xi_{E}^{2}\right)
$$

点 $\mathrm{E}$ の配向角および板厚 (Fig.1 の PF/EF) は次式で与. えられる.

$$
\theta_{E}=(1 / 2) \cos ^{-1} \xi_{E}, h_{E}=\left(1-\xi_{2}\right) /\left(1-\xi_{E}{ }^{2}\right)
$$

また，点 $\mathrm{F} に$ 対応する積層構成は $0^{\circ}, 90^{\circ}$ 材から成る 一般的なクロスプライ積層であり， $0^{\circ}, 90^{\circ}$ 材の板厚は 幾何学的関係より，それぞれ $h_{F} \cdot \mathrm{AF} / \mathrm{AB}, h_{F} \cdot \mathrm{BF} / \mathrm{AB}$ に よって与えられる.

$$
\begin{aligned}
& h_{0}=(1 / 2)\left(1+\xi_{F}\right) h_{F}, h_{90}=(1 / 2)\left(1-\xi_{F}\right) h_{F} \\
& h_{F}=1-h_{E} \\
\text { ここで, } & h_{F} \text { はクロスプライ積層の板厚を示す. }
\end{aligned}
$$

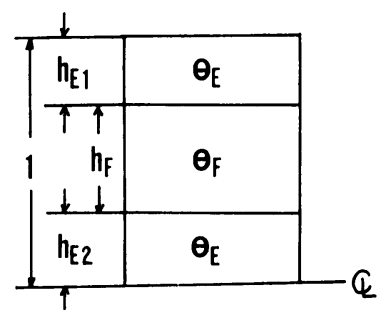

Fig.2 $[ \pm \theta \varepsilon / \pm \theta F / \pm \theta \varepsilon]_{s}$ laminate. 
点 $\mathrm{F}$ は $0^{\circ}, 90^{\circ}$ の 2 種類の配向角から成る一般的なク ロスプライ材に対応しているが，（19)式の関係を満たす ように $0^{\circ}$ 層と $90^{\circ}$ 層の非常に薄い層が交互に積層され た場合（これをクロスプライ層と呼ぶことにする）に は, 点 $\mathrm{F} に$ 対応する配向角を 1 種類の配向角とみなすこ とができる，このとき，面外積層パラメータの許容領域 は(11)式と同様に,

$$
\begin{gathered}
\left(\xi_{3}, \xi_{4}\right)=\left(\xi_{E}, \xi_{E^{2}}\right)+\lambda\left(\xi_{F}-\xi_{E}, 1-\xi_{E^{2}}\right) \\
h_{F}{ }^{3} \leqq \lambda \leqq 1-h_{E}{ }^{3}
\end{gathered}
$$

で与えられる. $\lambda=h_{F}{ }^{3}$ は点 Gに対応し， $\theta E$ 層が外層， クロスプライ層が内層となる積層構成を示し， $\lambda=1-$ $h_{E}{ }^{3}$ は点 $\mathrm{H}$ に対応し, クロスプライ層が外層, $\theta E$ 層が内 層となる積層構成を示す.

次に, 面内積層パラメータ $\left(\xi_{1}, \xi_{2}\right)$ に対応する点 $\mathrm{P}$, 面外積層パラメータ $\left(\xi_{3}, \xi_{4}\right)$ に対応する点Qが与えられ たとき，それに対応する積層構成は次のようにして求ま る. 值線 $\mathrm{PQ}$ と放物線との交点を $\left(\boldsymbol{\xi}_{E}, \boldsymbol{\xi}_{\boldsymbol{E}}{ }^{2}\right)$, 直線 $\mathrm{AB}$ との交点を $(\xi \boldsymbol{F}, 1)$ とする. 直線 $\mathrm{PQ}$ と放物線との交 点は(12)式より求まり, $\xi_{E}$ は

$$
\begin{array}{ll}
\xi_{E}=\bar{\xi}_{2} & \left(\left(\xi_{4}-\xi_{2}\right) /\left(\xi_{3}-\xi_{1}\right)<0 \text { のとき }\right), \\
\xi_{E}=\bar{\xi}_{1} & \left(\left(\xi_{4}-\xi_{2}\right) /\left(\xi_{3}-\xi_{1}\right)>0 \text { のとき }\right) \\
\xi_{E}=\bar{\xi}_{1} & \left(\xi_{3}=\xi_{1}, \xi_{4} \neq \xi_{2} \text { のとき }\right)
\end{array}
$$

で与えられる. ここで， $\bar{\xi}_{1}, \bar{\xi}_{2}$ は(12)式の根で $\bar{\xi}_{1}<\bar{\xi}_{2}$ と する.また， $\xi_{F}$ は

$$
\xi_{F}=\xi_{1}+\left(1-\xi_{2}\right)\left(\xi_{3}-\xi_{1}\right) /\left(\xi_{4}-\xi_{2}\right)
$$

で与えられる．点 $\mathrm{E} に$ 対応する層の配向角, 板厚は (18) 式，点 $\mathrm{F}$ に対応するクロスプライ層の板厚は(19)式,

Fig. 2 の積層構成（ただし $\theta F$ はクロスプライ層を示す） のときの $h_{E_{2}}$ は(16)式で与えられる。

次に， 2 種類の配向角をもつ積層材によって得られた 面外積層パラメータの許容領域は, 配向角の種類が多い 場合でも拡大しないことを示す.

いま，点 $\mathrm{P}$ の面内積層パラメータに対応する積層構成 を $n$ 種類の配向角 $\theta_{1}, \theta_{2}, \cdots, \theta_{n}$ （対応する点を $\mathrm{A}_{1}, \mathrm{~A}_{2}$, $\cdots, A_{n}$ とし $a_{1}, a_{2}, \cdots, a_{n}$ で示す）によって表示したと き, 点 $\mathrm{P}$ は $\mathrm{A}_{1} \mathrm{~A}_{2} \cdots \mathrm{A}_{n}$ の凸 $n$ 角形の内部あるいは周井 上に存在し点 $\mathrm{P}$ (p) は次のようになる (Fig.3 参照).

$$
\boldsymbol{p}=\sum_{i=1}^{n} h_{i} \boldsymbol{a}_{i}
$$

ここで, $h_{i}$ は $\theta_{i}$ の板厚で次の関係を満たす.

$$
\sum_{i=1}^{n} h_{i}=1, h_{i} \geqq 0
$$

$\boldsymbol{p}$ を $\boldsymbol{a}_{i}$ と $\boldsymbol{q}$ で次のように表示する.

$$
\boldsymbol{p}=h_{i} \boldsymbol{a}_{i}+\left(1-h_{i}\right) \boldsymbol{q}
$$

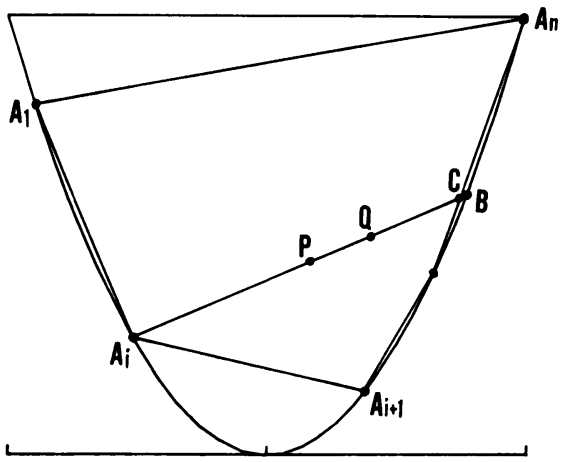

Fig. 3 Out-of-plane lamination parameter $\boldsymbol{q}$ on the line $\mathrm{A}_{i} \mathrm{~B}$.

$$
q=\frac{1}{1-h_{i}} \sum_{j \neq i} h_{j} a_{j}
$$

であり，(26)式より $\boldsymbol{q}$ は $\mathrm{A}_{i}$ 点を除いた凸 $(n-1)$ 角 形の内部あるいは周囲上に存在し，また，(25)式より直 線 $\mathrm{AB}$ 上に存在することがわかる. さらに，(25)式の $h_{i} \geqq 0,1-h_{i} \geqq 0$ より， $q$ は線分 $\mathrm{PC}$ 上に存在すること になる. 点 $\mathrm{P} か ゙ ~ \mathrm{~A}_{i}, \mathrm{~B}$ 点の 2 種類の配向角で表わされ たとき面外積層パラメータのとりらる領域は(11)式で示 されるのに対し, 点 $\mathrm{P}$ が $\mathrm{A}_{i} ， \mathrm{Q}$ 点で与えられたときに は直線 $\mathrm{A}_{i} \mathrm{~B}$ 上での面外積層パラメ一タの許容領域は (11)式で示される領域より狭くなることは明らかであ る.よって, 点 $\mathrm{P} 2$ 種類の配向角で表示して求めた面 外積層パラメータの許容領域が最大の許容領域となる.

\section{3 数 值 例}

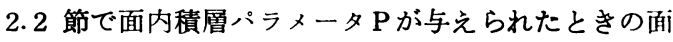
外積層パラメータの許容領域は (11) (20)式で示された. 数值例として, $\mathrm{P}(0,0.5)$ および $\mathrm{P}(0.2,0.4)$ のと きの面外積層パラメータの許容領域を Fig.4 に示す.

また，面内積層パラメータ $\mathrm{P}(0,0.5)$ ，面外積層パ ラメータ $\mathrm{Q}(0.3,0.4)$ のときの積層構成は (12) (10) (16)式を用いて次のように求められる.

$$
\left[ \pm 76.6^{\circ}{ }_{0.049} / \pm 30.0^{\circ}{ }_{0.615} / \pm 76.6^{\circ}{ }_{0.336}\right]_{s}
$$

ここで，下添字は各層の板厚を示す.

$\mathrm{P}(0,0.5), \mathrm{Q}(0.1,0.7)$ のとは, (21) (22) (18) (16) (19)式より

$$
\left[ \pm 51.5^{\circ}{ }_{0.083} /\left(0^{\circ} / 90^{\circ}\right)_{0.473} / \pm 51.5_{0.444}^{\circ}\right]_{s}
$$

となり, $\left(0^{\circ} / 90^{\circ}\right)$ は薄い $0^{\circ}, 90^{\circ}$ 層が交互に多数積層さ れたクロスプライ層で, $0^{\circ}, 90^{\circ}$ 層の板厚は

$$
h_{0}=0.296, h_{90}=0.177
$$

である. 


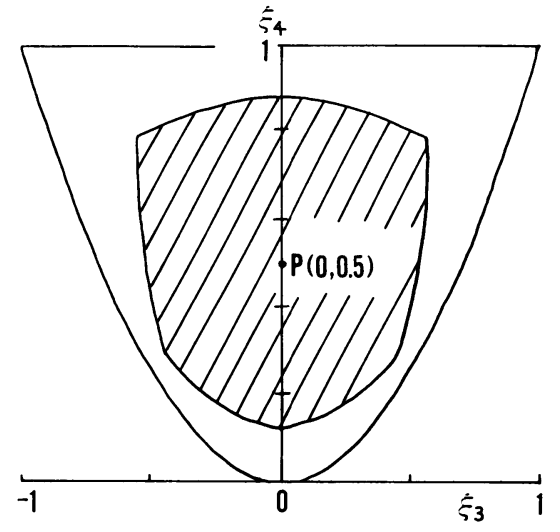

(a) $\mathrm{P}(0,0.5)$

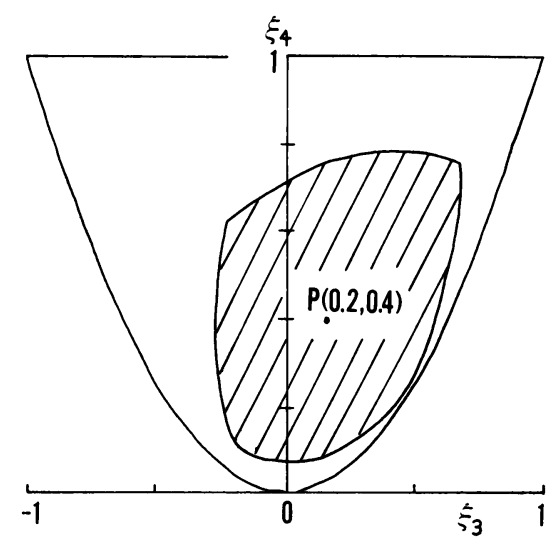

(b) $\mathrm{P}(0.2,0.4)$

Fig. 4 Maximum allowable region of out-ofplane lamination parameters.

\section{3. 直交異方性積層円筒殼の座届荷重を最大とする 積層構成}

カップリング効果を無視した值交異方性積層円筒殼に ついて座屈荷重を最大とする積層構成を求める.

軸方向圧縮荷重 $N_{x}$ ，周方向圧縮荷重 $N_{y}$ を受けると きの Donnell 型の座屈方程式は次式で与えられる。

$$
\begin{aligned}
& D_{11} w,_{x x x x}+2\left(D_{12}+2 D_{66}\right) w, x x y y+D_{22} w, y y y y \\
& \quad+(1 / R) U_{, x x}+N_{x} w_{x x}+N_{y, w, y y}=0 \\
& a_{22} U_{, x x x x}+\left(2 a_{12}+a_{66}\right) U_{, x x y y}+a_{11} U_{, y y y y} \\
& \quad-(1 / R) w_{, x x}=0
\end{aligned}
$$

ここで, $D_{i j}, a_{i j}$ はそれぞれ面外剛性, 面内コンプライ アンス, $w$ は面外撓み，Uは応力関数を示す．また，円 筒の板厚 $h$, 軸長 $L$, 半径 $R$ とする. $\mathrm{S} 2$ 単純支持境界 条件を満足する次の変位関数, 応力関数を仮定して,

$$
\begin{gathered}
w=\bar{w} \sin (\lambda / R) x \cos n \theta, \\
U=\bar{U} \sin (\lambda / R) x \cos n \theta \\
(\lambda=m \pi R / L)
\end{gathered}
$$

(27)式に代入すると次式が得られる.

$$
\begin{aligned}
& P= \frac{1}{R^{2}\left(k_{x} \lambda^{2}+k_{y} n^{2}\right)} \\
& \times\left[D_{11} \lambda^{4}+2\left(D_{12}+2 D_{66}\right) \lambda^{2} n^{2}+D_{22} n^{4}\right] \\
&+\frac{\lambda^{4}}{k_{x} \lambda^{2}+k_{y} n^{2}}-\frac{1}{a_{22} \lambda^{4}+\left(2 a_{12}+a_{66}\right) \lambda^{2} n^{2}+a_{11} n^{4}} \\
& \text { ここで, } k_{x}=N_{x} / P, k_{y}=N_{y} / P \text { である. }
\end{aligned}
$$

(29)式に拈いて右辺第 1 項は面外剛性, 第 2 項は面内コ ンプライアンスから成る項であり，座屈荷重は円筒の形 状 (半径, 板厚, 軸長) および積層構成（各層の緘維の 配向角，積層順序）が決まれば求めることができる.こ こでは，座屈荷重を最大とする積層構成を剛性に関する 不変量と面内および面外積層パラメータを用いて求める ことにする. まず，面内ュンプライアンス $a_{i j}$ は面内剛 性 $A_{i j}$ によって次のように与えられる.

$$
\left[\begin{array}{ccc}
a_{11} & a_{12} & 0 \\
a_{12} & a_{22} & 0 \\
0 & 0 & a_{66}
\end{array}\right]=\left[\begin{array}{ccc}
A_{11} & A_{12} & 0 \\
A_{12} & A_{22} & 0 \\
0 & 0 & A_{66}
\end{array}\right]^{-1}
$$

(2) 式と（30）式より，面内ュンプライアンス $a_{i j}$ は㴊 性に関する不変量と面内積層パラメータを用いて表わす と次のようになる.

$$
\begin{aligned}
& \varphi_{11} \equiv h a_{11}=\left(U_{1}-\xi_{1} U_{2}+\xi_{2} U_{3}\right) / \text { 分母 } \\
& \varphi_{12} \equiv h a_{12}=-\left(U_{4}-\xi_{2} U_{3}\right) / \text { 分母 } \\
& \varphi_{22} \equiv h a_{22}\left(U_{1}+\xi_{1} U_{2}+\xi_{2} U_{3}\right) / \text { 分母 } \\
& \varphi_{66} \equiv h a_{66}=1 /\left(U_{5}-\xi_{2} U_{3}\right) \\
& \text { 分母 }=\left(U_{1}+U_{4}\right)\left(U_{1}+2 \xi_{2} U_{3}-U_{4}\right)-\xi_{1}^{2} U_{2}^{2}
\end{aligned}
$$

また, $U_{i}$ に関して次の関係が成り立つ。

$$
U_{4}+2 U_{5}=U_{1}+2 U_{3}
$$

$D_{i j}$ を剛性に関する不変量と面外積層パラメータで表わ

し，同じょうに， $a_{i j}$ を㓮性に関する不変量と面内積層 パラメータで表示して，(29)式に代入する．このとき， (32)式を考慮すると, 座屈応力に関する次式が得られる.

$$
\begin{aligned}
\sigma \equiv \frac{P}{h}= & \frac{h^{2}}{12 R^{2}} \frac{\Phi_{1}}{k_{x} \lambda^{2}+k_{y} n^{2}} \\
& +\frac{\lambda^{4}}{k_{x} \lambda^{2}+k_{y} n^{2}} \frac{1}{\Phi_{2}} \\
\text { ここで, } \quad & \\
\Phi_{1}= & \left(U_{1}+\xi_{3} U_{2}+\xi_{4} U_{3}\right) \lambda^{4} \\
& +2\left(U_{1}+2 U_{3}-3 \xi_{4} U_{3}\right) \lambda^{2} n^{2} \\
& +\left(U_{1}-\xi_{3} U_{2}+\xi_{4} U_{3}\right) n^{4} \\
\Phi_{2}= & \varphi_{22} \lambda^{4}+\left(2 \varphi_{12}+\varphi_{66}\right) \lambda^{2} n^{2} \\
& +\varphi_{11} n^{4}
\end{aligned}
$$

ただし， $\varphi_{i j}$ は(31)式で示される量である. 
Table 1 Elastic constants of CFRP.

$$
\begin{aligned}
& E_{L}=142 \mathrm{GPa}, E_{T}=10.8 \mathrm{GPa}, G_{L T}=5.49 \mathrm{GPa}, v_{L}=0.3 \\
& U_{1}=45.6, U_{2}=66.1, U_{3}=31.3, U_{4}=34.6, U_{5}=36.8 \quad(\mathrm{GPa})
\end{aligned}
$$

積層構成を支配する $\xi_{1} \sim \xi_{4}$ が与えられたとき，座屈応 力 $\sigma$ は $m, n$ に関する最小値として与えられる。 た，座屈㐫力を最大とする積層構成は， $h / R, L / R$ が 与えられたとき， $\xi_{1} \sim \xi_{4}$ を設計変数とし。を目的関数と する最適化問題として定式化されるが，ここでは比較的 容易に解が求まり興味ある特性を示す $k_{x}=1\left(k_{y}=0\right)$ の 軸圧縮座屈と $k_{y}=1\left(k_{x}=0\right)$ の外圧座屈の場合をとりあ げる.

\section{1 王縮座届 $\left(k_{x}=1, k_{y}=0\right)$}

圧縮荷重を受ける積暊円筒殼の座屈特性, 圧縮座屈荷 重を最大とする積層構成に関する研究は多数の研究者に より行なわれてきた ${ }^{8-13)}$. 平野 ${ }^{11)}$ は，各層の配向角を設 計変数とする最適化問題として数理計画法による解析を 行ない，圧縮荷重を最大とする積層構成は多数存在する こと,また最適点では座屈荷重が座屈波数比 $n / \lambda$ に依存 しないといら結果を得た。また, 最近, 小野田 ${ }^{13)}$ はあら ゆる積層パラメータ（すべてのカップリング項を考虑す ると 12 の積層パラメータがある）を設計変数とする最 適化計算を行ない，最適構成に関する陽な関係式を得 た. その関係式では，カップリング効果のないときに は，等方性積層材が最適であるといら興味深い結論にな る.このよ5に圧縮座屈の最適積層を求める研究は，ほ とんど完成されているが，ここでは外圧座屈の場合の比 較のために，この問題をとりあげる.

圧縮座屈の場合には，此較的円筒が長ければ入を連続 変数とみなすことができ, $\lambda, n$ の代りに $\lambda, \mu(=n / \lambda)$ を連続変数として $\partial \sigma / \partial \lambda^{2}=0$ より，

$$
\begin{aligned}
\sigma= & (h / \sqrt{ } 3 R)\left[\left\{\left(U_{1}-\xi_{3} U_{2}+\xi_{4} U_{3}\right) \mu^{4}+2\left(U_{1}\right.\right.\right. \\
& \left.\left.+2 U_{3}-3 \xi_{4} U_{3}\right) \mu^{2}+\left(U_{1}+\xi_{3} U_{2}+\xi_{4} U_{3}\right)\right\} \\
& \left./\left\{\varphi_{11} \mu^{4}+\left(2 \varphi_{12}+\varphi_{66}\right) \mu^{2}+\varphi_{22}\right\}\right]^{1 / 2}
\end{aligned}
$$

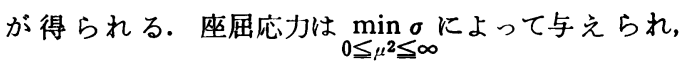

坐屈応力を最大とする $\xi_{1} \sim \xi_{4}$ は $\sigma$ が $\mu^{2}$ に依存しない といら次の条件から得られる（的が $\mu^{2}$ 飞依存しないと きの $\xi_{1} \sim \xi_{4}$ が最大の座屈応力を与えるといら解析的証 明はまだされていないが，小野田 ${ }^{13)}$ は数值計算によりこ の結論を得ている).

$$
\begin{aligned}
& \frac{U_{1}-\xi_{3} U_{2}+\xi_{4} U_{3}}{\varphi_{11}}=\frac{U_{1}+2 U_{3}-3 \xi_{4} U_{3}}{\varphi_{12}+\varphi_{66} / 2} \\
& =\frac{U_{1}+\xi_{3} U_{2}+\xi_{4} U_{3}}{\varphi_{22}}
\end{aligned}
$$

(36)式を満たす $\xi_{1} \sim \xi_{4}$ は唯一つ存在し，

$$
\xi_{1}=\xi_{3}=0, \xi_{2}=\xi_{4}=1 / 2
$$

となる. $\left(\xi_{1}, \xi_{2}\right)=(0,1 / 2)$ は $a_{11}=a_{22}, a_{66}=a_{11} / 2(1-$ $\left.a_{12} / a_{11}\right)$ と等価で面内等方性を意味する. 同様に（ $\xi_{3}$, $\left.\xi_{4}\right)=(0,1 / 2)$ 愐外等方性を意味する. 面内等方性, 面外等方性を満足する積層構成は 2 節での議論により 2 種類の配向角でも無数に存在することがわかる.

\section{2 外圧座届 $\left(k_{x}=0, k_{y}=1\right)$}

外任座屈荷重を最大とする積層構成を求める研究は, Nshanian ら ${ }^{10)}$ により各層の配向角を設計変数とする最 適化問題として行なわれている. また，積層構成，カッ プリング効果の外压座屈に及ばす影響については, 最 近, 粕谷ら ${ }^{14)}$ とよる研究がある。

本論文では, 外压座屈荷重を最大とする積層構成を単 純な仮定 ${ }^{15)}$ のとで求める. 外圧座屈の場合には，(33) 式で $\partial \sigma / \partial \lambda^{2}>0$ より $m=1$ のときに。は最小となる. $\mu=n / \lambda \gg 1$ と仮定して $\Phi_{1}, \Phi_{2}$ のなかのいちばん大き な項だけを残して $\partial \sigma / \partial n^{2}=0$ とすると备),

$$
\sigma=\frac{2 \pi}{3 \sqrt{ } 6} \frac{h \sqrt{ } h}{L} \sqrt{\bar{R}} \sqrt[4]{\frac{\left(U_{1}-\xi_{3} U_{2}+\xi_{4} U_{3}\right)^{3}}{\varphi_{11}}}
$$

が得られる。

Table 1 飞 CFRP 材の $U_{i}$ の值を示すが，このとき (38) 式より， $\left(\xi_{1}, \xi_{2}\right)$ と $\left(\xi_{3}, \xi_{4}\right)$ が独立な量であるなら ば, $\left(\xi_{1}, \xi_{2}\right)=(1,1),\left(\xi_{3}, \xi_{4}\right)=(-1,1)$ のときに $\sigma$ は 最大となる.すなわち, 面内剛性としては $0^{\circ}$ 材, 面外 剛性としては $90^{\circ}$ 材の特性を有するときが外圧座屈荷重 は最大となる。しかし，このような積層構成は存在しな い. ある $\xi_{1} ， \xi_{3}$ に対し， $\xi_{2} ， \xi_{4}$ は 1 のときに。は最大 となるので $\sigma$ の最大値は一般的なクロスプライ積層のな かに存在することがわかる．そこで $\boldsymbol{\xi}_{2}=\boldsymbol{\xi}_{4}=1$ とおき， $\xi_{1}, \xi_{3}$ について一方向探索により $\sigma$ を最大とする $\boldsymbol{\xi}_{1}, \boldsymbol{\xi}_{3}$ を求める. ただし，(11) 式で $\xi_{E}=-1, \xi_{F}=1$ とすると, $\xi_{3}$ には次の制約条件があることがわかる.

$$
-1+\left(1+\xi_{1}\right)^{3} / 4 \leqq \xi_{3} \leqq 1-\left(1-\xi_{1}\right)^{3} / 4
$$

数值例として, Table 1 に示す CFRP の塨合には, 外 
圧座屈荷重を最大とする $\xi_{1} \sim \xi_{4}$ は次の值をとる.

$$
\xi_{1}=-0.09, \xi_{2}=1, \xi_{3}=-0.81, \xi_{4}=1
$$

$\xi_{1}$ に対し $\xi_{3}$ は(39)式の下限值で, この積層パラメータ に対応する積層構成は 1 種類だけ存在し，(10) (12) (16) 式より,

$$
\left[90^{\circ}{ }_{0.55} / 0^{\circ}{ }_{0.45}\right]_{s}
$$

となる. また，このときの外圧座屈応力 $\sigma_{\mathrm{cr}}$ は，等方性 $\left(\xi_{1}=\xi_{3}=0, \xi_{2}=\xi_{4}=1 / 2\right)$ の座屈応力 $\sigma_{0}$ に対し

$$
\sigma_{c r} / \sigma_{0}=1.88
$$

となる。

軸圧縮座屈と外圧座屈とでは，座屈モードの違いから それぞれ(35)式（38)式のように近似的な支配方程式が 得られる。 その結果, 軸圧縮座屈では，（35）式の。が座 屈波数比 $\mu$ に体存しないといら条件から等方性積層が最 適の積層構成を与えた，一方，外圧座屈では，(38)式よ り $0^{\circ}$ 材に近い面内剛性と $90^{\circ}$ 材に近い面外剛性を有す る積層構成が最適の積層構成を与えることがわかり， (41)式で示す積層構成が得られた.

\section{4. 結 論}

積層円筒殼のように面内変形と面外変形とが連成する 問題の積層構成の最適化を行ならために，まず，面内積 層ハララメータと面外積層パラメータの関係を求め, 許容 領域内の積層パラメータに対応する積層構成を求めた. この結果を用いて, 積層円筒殼の圧縮, 外圧座屈荷重を 最大とする積層構成の問題を考察し，外圧の場 合には (41)式で示されるクロスプライ積層が最適の積層構成を 与えることを示した.

本論文では，カップリング効果を無視したが，カップ リング効果のあるときの積層パラメータ間の関係, 積層 パラメータと積層構成との関係を求めることが次の課題
である。

最後に，本研究に対し貴重なご助言，ご討論をいただ いた東京大学工学部平野陽一助教授に厚く感謝いたしま す.

\section{参考 文 献}

1）三木光範：日本機械学会論文集，48（1982), 1407-1414.

2）福永久雄：日本航空宇宙学会誌，30 (1982)，482489.

3) H. Fukunaga \& Y. Hirano: Proc. ICCM IV (1982), pp. 565-572.

4) 福永久雄, 平野陽一：材料システム，3 (1984), 135-141.

5) 三木光範 : 材料システム, 3 (1984)，83-98.

6) R.M. Jones : Mechanics of Composite Materials, McGraw-Hill Co., New York (1975).

7) S.W. Tsai \& H.T. Hahn: Introduction to Composite Materials, Technomic Publ. Co., Westport (1980).

8) J. Tasi : AIAA J., 4 (1966), 1058-1062.

9) 粕谷平和, 植村益次:日本航空宇宙学会誌, 30 (1982), 664-675.

10) Y.S. Nshanian \& M. Pappas: $A I A A$ J., 21 (1983), 430-437.

11）平野陽一：日本航空宇宙学会誌, 32 (1984), 4651.

12）小林繁夫，世古博已，広瀬一美：日本航空宇宙学 会誌, 32 (1984), 180-186.

13）小野田淳次郎：第 26 回構造強度に関する講演会 講演集 (1984), pp. 372-375.

14）粕谷平和, 植村益次 : 第 26 回構造強度に関する 講演会講演集 (1984), pp. 364-367.

15）林毅編：複合材料工学, 日科技連（1971）, pp. 821-822. 